\title{
EXPERIMENTAL EVALUATION OF ORGANIC SUBSTRATES FOR GERMINATION TESTING OF SOYBEAN SEED
}

\author{
Marija Milivojević ${ }^{1 \star}$, Dragana Branković-Radojčić ${ }^{1}$, Radmila Vukadinovićn \\ Jasna Kojić ${ }^{1}$, Zoran Dumanović ${ }^{1}$, Tanja Petrović ${ }^{1}$
}

\begin{abstract}
High germination of seeds and seedling establishment are critical for soybean production since it determines crop density and eventually affects the yield. Accurate evaluation of the germination potential of sowing material is valuable, as well as initial quality assessment of newly harvested seed. ISTA Rules prescribe alternative methods for soybean seed germination: sand, between paper, top of paper covered with sand and since 2020 organic growing media. In the Seed Testing Laboratory at the Maize Research Institute soybean germination is conducted in the sand at $20<=>30^{\circ} \mathrm{C}$. The objective of this study was to evaluate several available organic growing media and compare results obtained with the standard laboratory method. Five soybean seed lots of different quality were tested in four germination growing media ( 3 organic and sand), at two temperature regimes $\left(25^{\circ} \mathrm{C}\right.$ and $\left.20<=>30^{\circ} \mathrm{C}\right)$. Statistical analyses showed that all types of organic growing media were of the same quality. Slightly higher germination in organic growing media was obtained in the experiment at $20<=>30^{\circ} \mathrm{C}$ compared to sand, but those differences were not statistically significant. When testing was done in germinator with $25^{\circ} \mathrm{C}$ positive effects of organic growing media were identified and this impact was significant, especially for low-quality seed lots. The experimental outcome was to continue with routine practice and use organic growing media for retesting of seed lots with lower germination as an alternative substrate.
\end{abstract}

Key words: germination, organic substrate, sand, soybean, temperature

\section{Introduction}

Soybean (Glycine max) is a very important oilseed crop worldwide (Singh and Shivakumar, 2010). High germination and uniform seedling establishment are critical for soybean production since they determine crop density and eventually affect the yield (Singh et al., 2009). Soybean seed production is demanding, and timely harvest is exceptionally important in maintaining high-quality seeds. Soybean seed quality is largely influenced by seed manipulation during the harvest and processing (Đukanović et al., 2000). Harvest of soybean with moisture below $10 \%$ leads to significant seed damage and loss of germination and viability (Vujaković, 2019). Therefore, accurate evaluation of sowing material germination po- tential is valuable, as well as initial quality assessment of newly harvested seed. Rules of the International Seed Testing Association (ISTA) prescribe several methods for testing seed germination for the majority of species. For germination of soybean seed sand (S), between paper (BP) and top of paper covered with sand (TPS) were listed in the Table 5A of ISTA Rules until 2020 when the new organic substrate (O) was introduced. The validation study was conducted by the ISTA Germination technical committee to approve the use of Organic growing media. The results showed that higher germination was obtained with organic growing media compared to other substrates. Also, better repeatability and reproducibility were achieved in comparing to existing methods.

Original Scientific Paper (Originalni naučni rad)

${ }^{1}$ Milivojević M, Branković-Radojčić D, Vukadinović R, Kojić J, Dumanović Z, Petrović T, Maize Research Institute

Zemun Polje, Slobodana Bajića 1, 11185, Zemun, Belgrade, Serbia

*e-mail:mmarija@mrizp.rs 
In the Seed Testing Laboratory at the Maize Research Institute (LIZP), soybean germination is conducted in the sand. This method was chosen as a preferred one since it was constantly giving better results than BP method. From the moment the validation study was published at the ISTA website, laboratory decided to set up the experiment for evaluation of several available organic growing media that could be used in everyday practice. ISTA Rules (2020) define "organic growing media" as a mixture of organic fibres (such as peat, coconut, or wood fibres, with size less than $5 \mathrm{~mm}$ ) and mineral particles (such as sand, perlite, dolomite and vermiculite; comprising 15-30\% by volume). Previously, organic growing media was allowed for initial germination testing of sunflowers and fava beans. It is also permitted for comparative testing and retesting of other species.

\section{Material and method Seed material}

Five soybean seed lots were selected for the experiment according to previous testing results in the sand. The germination percentage ranged from $77 \%$ to $94 \%$. Seed lots were from different varieties and the seed was not chemically treated.

\section{Organic growing media}

Four different organic substrates from two suppliers were purchased for the evaluation study. Two substrates were pure peat $(\mathrm{O} 1, \mathrm{O} 2)$, while the other two substrates contained $10 \%$ of perlite $(\mathrm{O} 3, \mathrm{O} 4)$. For the germination testing, all substrates were mixed with sterilized fine sand to obtain $20-30 \%$ in volume mineral component (ISTA, 2020). After preliminary testing, one organic substrate was excluded (O4) from the experiment due to the presence of large non-decayed wooden particles.

\section{Germination tests}

For the evaluation study, four different germination growing media were used (3 organic and sand), and two different temperature regimes $\left(25^{\circ} \mathrm{C}\right.$ and $\left.20<=>30^{\circ} \mathrm{C}\right)$. Four replicates of 100 seeds were used for each testing method. During germination $8 / 16 \mathrm{~h}$ light/dark regime was used. Germination evaluation was conducted after 8 days according to ISTA Rules (2020) and Handbook on seedling evaluation (ISTA, 2018).

\section{Statistical analyses}

Data were processed by the three-way analysis of variance (ANOVA) for germination results. The significance of differences between mean values was tested by LSD test.

\section{Results and discussion}

Experimental results confirmed that seed lots were of different quality (Figure 1 and 2). Observing the overall average, seed lot 5 had the highest germination (94\%), followed by seed lot 2 (91\%), seed lot 3 (90\%) and seed lot 1 (81\%). Seed lot 4 had the lowest germination (71\% overall average). Variable seed quality provided a good base for a complete evaluation. Statis-

Table 1.ANOVA, F-test values for soybean germination of five seed lots in organic substrates and sand at two temperature regimes

Tabela 1. Vrednosti F testa iz ANOVA za klijavost pet partija semena soje u organskom supstratu i pesku u dva temperaturna režima

\begin{tabular}{lc}
\hline Source of variation & F-test values \\
\hline Temperature (A) & $6.30^{*}$ \\
Seed lot (B) & $143.52^{* *}$ \\
AxB & $2.05^{\text {ns }}$ \\
Substrate (C) & $11.28^{* *}$ \\
AxC & $5.04^{* *}$ \\
BxC & $1.37 \mathrm{~ns}$ \\
AxBxC & $4.34^{* *}$ \\
\hline
\end{tabular}

$n s-$ statisticaly non significant; ${ }^{\star} p<0.05 ;{ }^{* *} p<0.01$ 
tical analyses showed a significant effect of all interactions (substrate $\mathrm{x}$ temperature) provided applied factors: germinating temperature, seed a better understanding of substrates impact in lot and substrate (Table 1). Further analysis of different growing conditions (Table 2).

Table 2. Interactions of growing substrates $(\mathrm{O} 1, \mathrm{O} 2, \mathrm{O} 3$ and $\mathrm{S})$ and temperatures $\left(20<=>30^{\circ} \mathrm{C}\right.$ and $\left.25^{\circ} \mathrm{C}\right)$ for soybean germination

Tabela 2. Interakcije izmedu supstrata $(\mathrm{O} 1, \mathrm{O} 2, \mathrm{O} 3$ i S $)$ i temperatura $\left(20<=>30^{\circ} \mathrm{C}\right.$ i $\left.25^{\circ} \mathrm{C}\right)$ za naklijavanje soje

\begin{tabular}{ccccc}
\hline Substrate & $\begin{array}{c}\text { Temperature } \\
\left({ }^{\circ} \mathbf{C}\right)\end{array}$ & $\begin{array}{c}\text { Normal seedlings } \\
(\%)\end{array}$ & $\begin{array}{c}\text { Abnormal seedlings } \\
(\%)\end{array}$ & $\begin{array}{c}\text { Dead seeds } \\
(\%)\end{array}$ \\
\hline \multirow{2}{*}{ O1 } & $20<=>30$ & $87.1^{\mathrm{a}}$ & $9.2^{\mathrm{b}}$ & $3.7^{\mathrm{c}}$ \\
& 25 & $86.9^{\mathrm{a}}$ & $9.7^{\mathrm{b}}$ & $3.4^{\mathrm{c}}$ \\
$\mathrm{O} 2$ & $20<=>30$ & $85.7^{\mathrm{a}}$ & $10.1^{\mathrm{b}}$ & $4.2^{\mathrm{bc}}$ \\
& 25 & $84.9^{\mathrm{a}}$ & $9.0^{\mathrm{b}}$ & $6.1^{\mathrm{ab}}$ \\
$\mathrm{O} 3$ & $20<=>30$ & $85.5^{\mathrm{a}}$ & $9.0^{\mathrm{b}}$ & $5.5^{\mathrm{abc}}$ \\
& 25 & $86.9^{\mathrm{a}}$ & $9.8^{\mathrm{b}}$ & $4.3^{\mathrm{bc}}$ \\
$\mathrm{S}$ & $20<=>30$ & $86.5^{\mathrm{a}}$ & $9.1^{\mathrm{b}}$ & $4.4^{\mathrm{bc}}$ \\
& 25 & $78.7^{\mathrm{b}}$ & $13.8^{\mathrm{a}}$ & $7.5^{\mathrm{a}}$ \\
\hline
\end{tabular}

Means followed by the same letter are not significantly different according to the $\mathrm{LSD}_{0.05}$

Results showed that all types of organic growing media were of the same quality. Germination of soybean seed was comparable in all substrates used in the experiment at $20<=>30^{\circ} \mathrm{C}$. Percentages of normal seedlings achieved in the organic growing media $\mathrm{O} 1$ and $\mathrm{O} 2$ were slightly higher than in sand, but those differences were not statistically significant. When testing was done in germinator at $25^{\circ} \mathrm{C}$, positive effects of organic growing media were identified and this impact was significant. The conducted evaluation was partly in accordance with the ISTA validation study (Garreau and Ducournau, 2019a). Their germination results in organic growing media were better than in other existing substrates, under both temperature regimes $\left(20<=>30^{\circ} \mathrm{C}\right.$ and $\left.25^{\circ} \mathrm{C}\right)$. Better germination in organic growing media authors explained by the production of fewer abnormal seedlings and non-germinated seeds. This tendency was also seen in our tests conducted at temperature $25^{\circ} \mathrm{C}$.

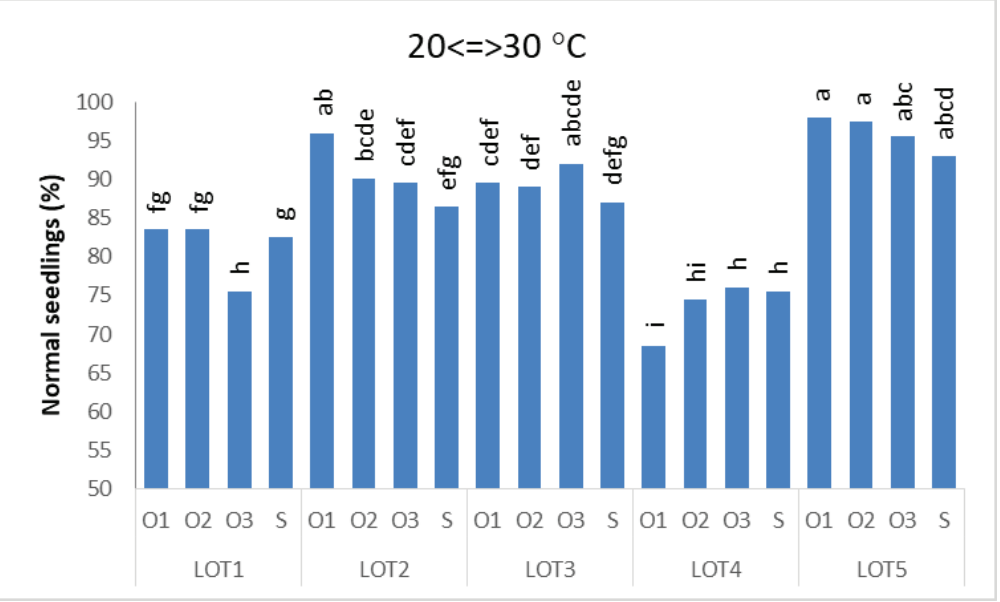

Figure 1. Percentage of normal soybean seedlings of five seed lots germinated in three organic substrates (O1, $\mathrm{O} 2$ and $\mathrm{O} 3)$ and sand (S) at $20<=>30^{\circ} \mathrm{C}$ Means presented in bars with no letters in common are significantly different according to the LSD ${ }_{0.05}$

Grafikon 1. Procenat normalnih klijanaca ostvaren $u$ ispitivanju klijavosti pet partija semena soje u tri organska supstrata i pesku na temperaturi $20<=>30^{\circ} \mathrm{C}$ 
On the figures 1 and 2 germination results for each seed lot in every substrate were presented separately. When $20<=>30^{\circ} \mathrm{C}$ germination method was applied (Figure 1), three seed lots (lot2, lot3 and lot5) obtained the lowest germination in the sand. Interestingly, those seed lots had better quality than the other two.
Only organic substrate $\mathrm{O} 1$ in seed lot2 had significantly better results compared to sand.

On the contrary, soybean germination at $25^{\circ} \mathrm{C}$ revealed that lower quality seed lots had a huge decreasein normal seedlings in the sand (Figure 2). Four out of five seed lots gave better results in organic growing media in this method.

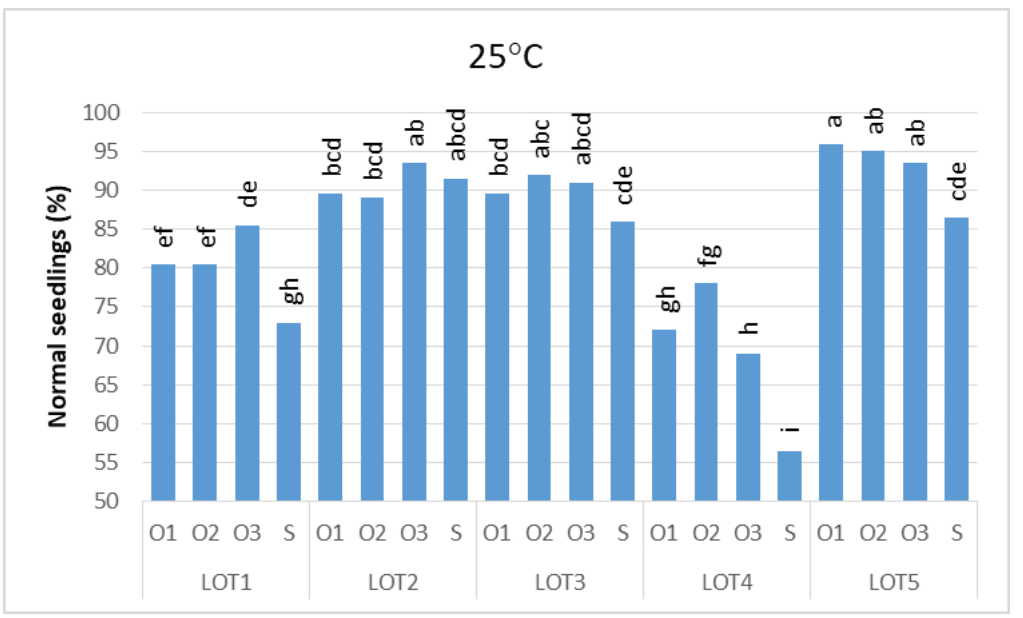

Figure 2. Percentage of normal soybean seedlings of five seed lots germinated in three organic substrates $(\mathrm{O} 1, \mathrm{O} 2$ and $\mathrm{O} 3)$ and sand (S) at $25^{\circ} \mathrm{C}$

Means presented in bars with no letters in common are significantly different according to the $L S D_{0.05}$

Grafikon 2. Procenat normalnih klijanaca ostvaren $u$ ispitivanju klijavosti pet partija semena soje $u$ tri organska supstrata $i$ pesku na temperaturi $25^{\circ} \mathrm{C}$

Previous research in the LIZP showed that addition of zeolite in sand and soil is promoting soybean germination producing stronger seedlings with well-developed roots and hypocotyls. The highest germination was achieved in sand with $3 \%$ zeolite. The presence of zeolite provided a loosened and sufficiently wet medium that provided easer extraction of seedlings (Kojić et al., 2018).
Organic substrates mixed with sand in this experiment also formed excellent growing media for germination of soybean seed. Peat was very light and easy for use, with very high water holding capacity and also very well aerated. That is very important in the case of seed lots with lower quality. Seedlings were well developed and slightly bigger than those germinated in the sand (Photo 1). Johnston (2013) report-

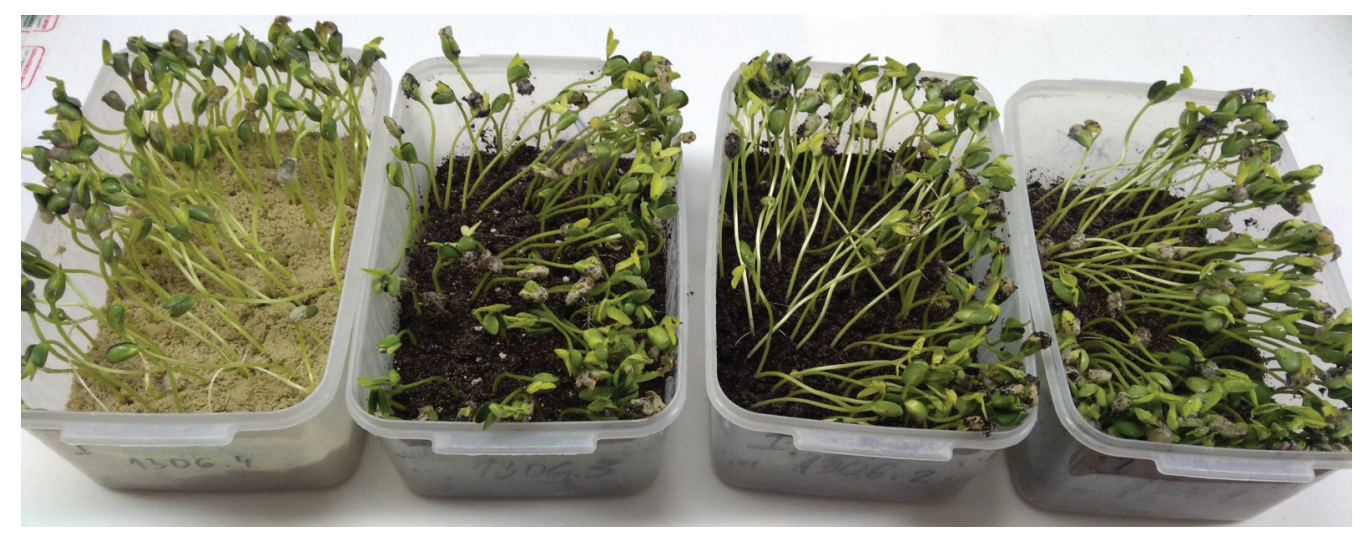

Photo 1. Soybean seedlings after eight days germination in different organic substrates and sand Fotografija 1. Klijanci soje osam dana nakon klijanja u različitim organskim supstratima i pesku 
ed higher germination with larger seedlings obtained in an organic substrate in the referee test in America. The objective of that study was to compare germination of a bean using paper (i.e. towel/Kimpac), sand and organic media. Subsequently, ISTA validation study confirmed those results and organic growing media was added as a primary germination media for bean in the ISTA Rules (Garreau and Ducournau, 2019b).

Introduction of organic growing media as a primary substrate will give laboratories more flexibility and will reduce the workload created by parallel testing or retesting.

\section{Conclusion}

Experimental evaluation of organic growing media showed that benefits are significant when germinating soybean at $25^{\circ} \mathrm{C}$. Slightly higher germination in organic growing media was obtained in the experiment at $20<=>30^{\circ} \mathrm{C}$ compared to sand as a standard laboratory method. Experimental data showed that those differences were not significant, so it was decided to continue with routine practice, and use organic substrate for retesting of seed lots with lower germination.

\section{References}

Đukanović L, Srebrić M, Milićević M, Pavlov M (2000): Uticaj načina žetve i dorade na životnu sposobnost semena soje. Selekcija i semenarstvo. Vol 7, (3-4): 33-36.

Garreau P and Ducournau S (2019a): Germination Committee Technical report: Validation of germination method for Glycine max using Organic $(\mathrm{O})$ growing media to support C.5.1.a. ISTA Method validation reports for 2020 edition of ISTA Rules. Available in https://www.seedtest.org/upload/cms/user/OGM19-07ISTAMethodValidationReports1.pdf (15 ${ }^{\text {th }}$ June, 2020)

Garreau P and Ducournau S (2019b): Germination Committee Technical report: Validation of germination method for Phaseolus vulgaris using Organic $(\mathrm{O})$ growing media to support C.5.1.b. ISTA Method validation reports for 2020 edition of ISTA Rules. Available in https://www.seedtest. org/upload/cms/user/OGM19-07ISTAMethodValidationReports1.pdf (15 ${ }^{\text {th }}$ June, 2020)

ISTA International Seed Testing Association (2020): International Rules for Seed Testing, edition 2020. ISTA Bassersdorf, Switzerland.

ISTA International Seed Testing Association (2018). ISTA Handbook on Seedling Evaluations, $4^{\text {rd }}$ Edition, International Seed Testing Association, Bassersdorf, Switzerland.

Johnston DM (2013): OSA/SCST Region IV - Southwest Referee 2013 Phaseolus vulgaris - Organic Media Comparative Germination Testing. Available in https://www. google.com $/$ search? source $=$ univ\&tbm $=$ isch\&q=organic + growing + media + in + seed +testing\&sa $=X \& v e d=2$ ahUKEwiW8q-_mPzpAhWMlIsKHdXHAG4QsAR6BAgHEAE\&biw $=1034 \&$ bih $=640\left(15^{\text {th }}\right.$ June, 2020 $)$

Kojić J, Radosavljević N, Petrović T, Milivojević M (2018): Effects of zeolite on germination of soya bean seed and its use as a substrate. Book of Proceedings. IX International Scientific Agriculture Symposium "Agrosym 2018", Jahorina, October 4-7, 2018, 315-319.

Moshtaghi-Khavaran A, Khomari S, Zare N (2014): Soybean seed germination and seedling growth in response to deterioration and priming: effect of seed size. Plant breeding and seed science. Volume 70. DOI: $10.1515 /$ plass-2015-0013

Singh NI, Seema A, Chauhan JS (2009): Effect of seed size on quality within seed lot of pea and correlation of standard germination and vigour with field emergence test. Nature Sci. 7(4): 72-78.

Singh G and Shivakumar BG (2010): The role of soybean in agriculture. The Soybean: Botany, Production and Uses. 24-47.

Vujaković M (2019): Parametri koji utiču na kvalitet semena soje. Za našu zemlju. Broj 75 , str. 28. 


\title{
EKSPERIMENTALNA PROCENA ORGANSKIH PODLOGA ZA ISPITIVANJE KLIJAVOSTI SEMENA SOJE
}

\author{
Marija Milivojević, Dragana Branković-Radojčić, \\ Radmila Vukadinović, Jasna Kojić, \\ Zoran Dumanović, Tanja Petrović
}

\begin{abstract}
Sažetak
Visoka klijavost semena i uniforman rast klijanaca su presudni za proizvodnju soje, jer od toga zavisi gustina useva i na kraju, prinos. Precizna procena potencijala klijavosti setvenog materijala je izuzetno važna, kao i početna procena kvaliteta tek požnjevenog semena. Međunarodna pravila za ispitivanje semena propisuju alternativne metode za klijanje semena soje: pesak, između filter papira, na filter papiru uz prekrivanje peskom, i od 2020. godine organski supstrat. U Laboratoriji za ispitivanje semena, Instituta za kukuruz "Zemun Polje”, naklijavanje soje se vrši u pesku, na temperaturi $20<=>30^{\circ} \mathrm{C}$. Cilj ove studije bio je proceniti nekoliko dostupnih organskih supstrata i uporediti dobijene rezultate sa dosadašnjom laboratorijskom metodom. Pet partija soje različitog kvaliteta testirano je u četiri podloge za naklijavanje ( 3 organske i pesak), pri dva temperaturna režima $\left(25^{\circ} \mathrm{C}\right.$ i $\left.20<=>30^{\circ} \mathrm{C}\right)$. Statistička analiza pokazala je da su sve organske podloge istog kvaliteta. Nešto veća klijavost u organskom supstratu u poređenju sa peskom je ostvarena u eksperimentu na $20<=>30^{\circ} \mathrm{C}$, ali te razlike nisu bile statistički značajne. Prilikom ispitivanja u klijalištu sa $25^{\circ} \mathrm{C}$ pokazali su se pozitivni efekti organske podloge i ovaj uticaj je bio značajan, posebno za partije slabijeg kvaliteta. Nakon analize eksperimentalnih rezultata odlučeno je da se nastavi sa dosadašnjom laboratorijskom praksom naklijavanja u pesku i da se organska podloga koristi kao alternativni supstrat za ponovno ispitivanje partija semena sa nižim procentom klijavosti.
\end{abstract}

Ključne reči: soja, klijavost, organski supstrat, pesak, temperature

Primljen: 19.06.2020.

Prihvaćen: 3.08.2020. 